\title{
Influence of Nitrogen Rate, Seeding Rate, and Weed Removal Timing on Weed Interference in Barley and Effect of Nitrogen on Weed Response to Herbicides
}

\author{
Vipan Kumar, and Prashant Jha*
}

Field experiments were conducted at the Montana State University Southern Agricultural Research Center, Huntley, MT, in 2011 through 2013 to determine the effect of nitrogen $(\mathrm{N})$ rate, seeding rate, and weed removal timing on weed interference in barley. A delay in weed removal timing from the 3- to 4-leaf (LF) stage to the 8- to 10-LF stage of barley resulted in up to 3.5-fold increase in total weed biomass and $10 \%$ reduction in barley biomass, and this was unaffected by a $\mathrm{N}$ rate that ranged from 56 (low) to 168 (high) $\mathrm{kg} \mathrm{ha}^{-1}$. The effect of $\mathrm{N}$ rate on barley biomass was more pronounced when weed removal was delayed from the 3- to 4-LF stage to the 8- to 10-LF stage of barley and in nontreated plots. Increasing the barley seeding rate from 38 to $152 \mathrm{~kg} \mathrm{ha}^{-1}$ increased the barley plant density by $50 \%$, biomass by $13 \%$, and grain yield by $29 \%$, averaged over $\mathrm{N}$ rates and weed removal timing. On the basis of 5 and $10 \%$ levels of acceptable yield loss, the addition of $\geq 112 \mathrm{~kg}$ $\mathrm{N} \mathrm{ha}{ }^{-1}$ delayed the critical timing of weed removal by at least $1.3 \mathrm{wk}$ in barley, compared with the $56 \mathrm{~kg} \mathrm{~N} \mathrm{ha}^{-1}$ rate. A medium or high $\mathrm{N}$ rate prevented reduction in barley grain quality (plumpness and test weight) observed when the seeding rate was increased from 38 to 76 or $152 \mathrm{~kg} \mathrm{ha}^{-1}$ at the low $\mathrm{N}$ rate. In a separate greenhouse study, the effect of $\mathrm{N}$ rate on the effectiveness of various herbicides for controlling wild oat, green foxtail, kochia, or Russian thistle was investigated. Results highlighted that wild oat or green foxtail grown under $56 \mathrm{~kg} \mathrm{~N} \mathrm{ha}^{-1}$ (low N) soil required 1.4 to 2.6 times higher doses of clodinafop, fenoxaprop, flucarbazone, glyphosate, glufosinate, pinoxaden, or tralkoxydim for $50 \%$ reduction in shoot dry weights $\left(\mathrm{GR}_{50}\right)$ compared with plants grown under $168 \mathrm{~kg} \mathrm{~N} \mathrm{ha}^{-1}$ (high N). Similarly, a reduced efficacy of thifensulfuron methyl + tribenuron methyl, metsulfuron methyl, or bromoxynil + pyrasulfotole was observed (evident from the $\mathrm{GR}_{50}$ values) for kochia or Russian thistle grown under low- vs. high-N soil. Information gained from this research will aid in developing cost-effective, integrated weed management (IWM) strategies in cereals and in educating growers on the importance of fertilizer $\mathrm{N}$ management as a component of IWM programs.

Nomenclature: Bromoxynil + pyrasulfotole; clodinafop; fenoxaprop; flucarbazone; glyphosate; glufosinate; metsulfuron methyl; pinoxaden; thifensulfuron methyl + tribenuron methyl; tralkoxydim; green foxtail; Setaria viridis (L.) Beauv.; kochia, Kochia scoparia (L.) Schrad; Russian thistle, Salsola tragus L.; barley, Hordeum vulgare L.; wild oat, Avena fatua L.

Key words: Nitrogen, seeding rate, critical timing of weed removal (CTWR), herbicide-weed complex, integrated weed management (IWM).

Barley is an important commercial crop well suited for both irrigated and dryland cropping systems of the Northern Great Plains (NGP), including Montana. In 2014, Montana ranked second among the barleyproducing states, with $25.3 \%$ of the total U.S. barley production (U.S. Department of Agriculture 2015). Barley is primarily grown in rotation with sugar beet (Beta vulgaris L.) and corn (Zea mays L.) under irrigation, as an alternative to wheat (Triticum aestivum L.) in dryland crop production, and as an annual forage crop in Montana (McVay et al. 2009). Barley is

\footnotetext{
DOI: 10.1614/WS-D-16-00047.1

* First and second authors: Postdoctoral Research Associate and Associate Professor, Montana State University, Southern Agricultural Research Center, 748 Railroad Highway, Huntley, MT 59037. Corresponding author's E-mail: pjha@montana.edu
}

primarily used for malting and animal feedstock and as a grain for human consumption (McVay et al. 2009).

Weed management is a major challenge in the successful production of small grain crops in the NGP (Derksen et al. 2002). If not managed, infestations of grass and broadleaf weeds reduce yield and quality of cereal grains. For example, season-long interference of wild oat at densities of 84 to 191 plants $\mathrm{m}^{-2}$ reduced wheat yields up to $39 \%$ and barley yields up to 26\% (Bell and Nalewaja 1968). A season-long interference from kochia, a broadleaf weed, at densities of 4 to 70 plants $\mathrm{m}^{-2}$ reduced spring wheat yields by 22 to $58 \%$ (Dahl 1982).

Herbicides are a major tool for weed control in small grain production systems. However, the repeated use of the same site-of-action herbicides has resulted in escalating cases of herbicide-resistant (HR) weed evolution in cereal production (Heap 2015). Cross or 
multiple HR biotypes of wild oat, green foxtail, kochia, and Russian thistle have been documented in the NGP, including Montana (Heap 2015; Jha et al. 2015; Kumar et al. 2014, 2015). Effective, alternative herbicide options are currently limited in cereals, necessitating the adoption of integrated weed management (IWM) strategies.

Nitrogen $(\mathrm{N})$ is one of the most important agricultural inputs that influences the crop-weed interference (Swanton et al. 2015). Previous studies on the effect of $\mathrm{N}$ rate on crop-weed competition have shown variable outcomes. For instance, Abouziena et al. (2007) reported that increasing $\mathrm{N}$ rate from 300 to $338 \mathrm{~kg} \mathrm{ha}^{-1}$ increased corn grain yield by $18 \%$ and decreased total weed dry weight by $14 \%$. In contrast, Peterson and Nalewaja (1992) found that fertilizer N applied at twice the recommended rate increased the green foxtail biomass from 41 to $75 \%$, with no increase in the wheat biomass, suggesting that the green foxtail was at a competitive advantage relative to the wheat. There is a limited literature on the effect of $\mathrm{N}$ rate on weed interference in barley.

Crop seeding rates can also influence weed interference in cereals (Blackshaw et al. 2000; Mohler 2001; Scursoni and Satorre 2005). Blackshaw et al. (2000) reported that increasing wheat seeding rates from 50 to $300 \mathrm{~kg} \mathrm{ha}^{-1}$ over $4 \mathrm{yr}$ reduced the seedbank of redstem filaree (Erodium cicutarium L.) by $>75 \%$. Similarly, a high barley density of 280 plants $\mathrm{m}^{-2}$ reduced wild oat biomass compared with the low (160 plants $\mathrm{m}^{-2}$ ) and medium (220 plants $\mathrm{m}^{-2}$ ) crop densities, which increased wild oat interference and reduced barley yield by $25 \%$ (Scursoni and Satorre 2005).

Weed removal timing is another important cultural practice that influences crop yield losses (Knezevic et al. 2002; Kumar and Jha 2015; Norsworthy and Oliveira 2004). Knowledge of the critical period of weed control (CPWC) is often required to determine the crop growth stage when weeds must be controlled to avoid unacceptable crop yield loss (Knezevic et al. 2002; Knezevic and Datta 2015). The CPWC is an interval between the critical timing of weed removal (CTWR) and the critical weed-free period (CWFP) (Knezevic and Datta 2015). According to Knezevic et al. (2002: 774): "The CTWR is the maximum duration of earlyseason weed competition that can be tolerated by the crop before it suffers irrevocable yield loss, and the CWFP is the minimum weed-free period required from the time of planting to prevent an unacceptable crop yield loss." The CPWC and its components are influenced by several factors, including crop seeding rates and fertilizer inputs (Evans et al. 2003a, 2003b; Godara et al. 2012).

Soil N levels can influence herbicides' efficacy on some weed species. Dickson et al. (1990) reported that oats (Avena sativa L.) grown under low $\mathrm{N}$ $\left(1 \mathrm{~mol} \mathrm{~m} \mathrm{~m}^{-3}\right)$ had less control with fluazifop and glyphosate compared with those grown under high $\mathrm{N}\left(10 \mathrm{~mol} \mathrm{~m}^{-3}\right)$. Cathcart et al. (2004) observed that the efficacy of nicosulfuron, glufosinate, mesotrione, and glyphosate herbicides was less on green foxtail, redroot pigweed, and velvetleaf (Abutilon threophrast $i$ Medik.) grown under low $(0.7 \mathrm{mM})$ vs. high soil $\mathrm{N}$ (7.7 $\mathrm{mM})$. However, the herbicide by $\mathrm{N}$ interaction was not evident for all herbicide-weed species complexes. For instance, the percent control and shoot dry weight reduction of velvetleaf treated with glufosinate and mesotrione did not differ across soil $\mathrm{N}$ levels (Cathcart et al. 2004). Consequently, it is critical to understand the relationship between soilapplied $\mathrm{N}$ rate and herbicide efficacy on the weed species predominant in the cereal production systems of the NGP to prevent weed control failures.

There is a lack of information in the literature on the interaction of $\mathrm{N}$ rate, seeding rate, and weed removal timing on weed interference in barley production. Also, the effect of $\mathrm{N}$ rate on the efficacy of selected POST herbicides on the predominant weed species (wild oat, green foxtail, kochia, and Russian thistle) in cereals is unknown. Therefore, the objectives of this research were (1) to quantify the weed interference in barley under varying $\mathrm{N}$ rates, seeding rates, and weed removal timings; and (2) to investigate the effect of $\mathrm{N}$ rate on the efficacy of selected POST herbicides on the predominant grass and broadleaf weed species in NGP cereal production.

\section{Materials and Methods}

Field Experiments. Field experiments were conducted from 2011 through 2013 at the Montana State University (MSU) Southern Agricultural Research Center (SARC) near Huntley, MT. The soil type at the study site was Fort Collins clay loam (fine-loamy, mixed, superactive, mesic Aridic Haplustalfs) with an organic matter of $2.8 \%$ and a $\mathrm{pH}$ of 8.1. The maximum and minimum air temperatures recorded during the three barley-growing seasons (2011, 2012, and 2013) are shown in Figure 1. The experimental site was under irrigated barleysugar beet rotation for a minimum of $5 \mathrm{yr}$ prior to the initiation of the study. Bromoxynil plus MCPA (Bronate Advanced $^{\mathrm{TM}}$; Bayer CropScience, Research 

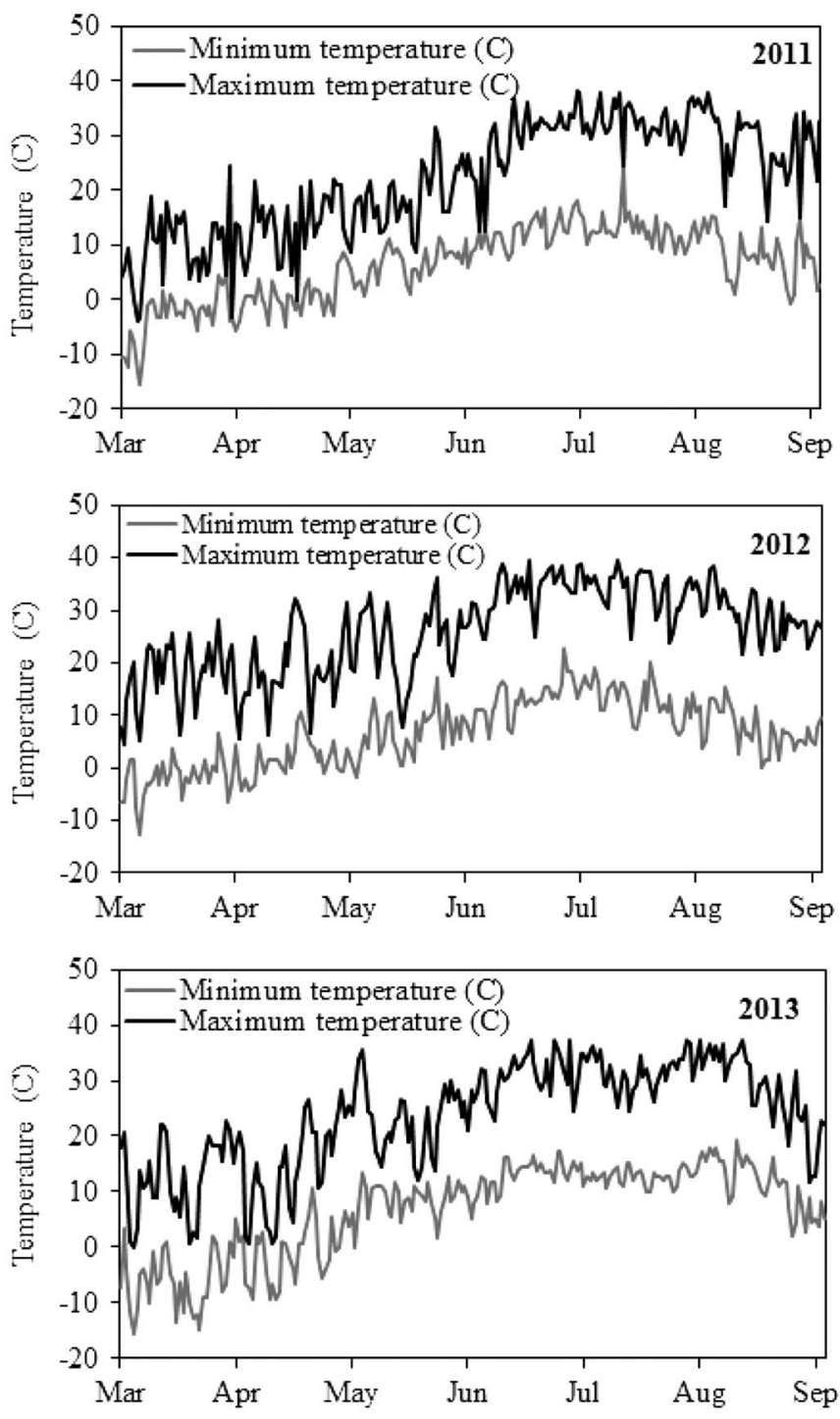

Figure 1. Daily minimum and maximum air temperatures during the barley-growing seasons in 2011, 2012, and 2013 near Huntley, MT.

Triangle Park, NC 27709) at $1,120 \mathrm{~g} \mathrm{ha}^{-1}$ and pinoxaden (Axial ${ }^{\circledR} \mathrm{XL}$; Syngenta Crop Protection, Greensboro, NC 27419) at $60 \mathrm{~g} \mathrm{ha}^{-1}$ were used for broadleaf and grass weed control, respectively, in barley. Two to three applications of glyphosate
(Roundup PowerMax ${ }^{\circledR}$; Monsanto, 800 North Lindbergh Boulevard, St. Louis, MO 63141) at $870 \mathrm{~g} \mathrm{ha}^{-1}$ were used for season-long weed control in the glyphosate-resistant sugar beet grown in rotation.

Experiments were conducted in separate fields each year to avoid any effect of differential $\mathrm{N}$ rates in the previous year. Land preparation at the study site involved disking and roller harrowing in the fall followed by cultivation and leveling in the spring. Before planting, 30 soil samples were collected from each depth: 0 to $15 \mathrm{~cm}, 15$ to $30 \mathrm{~cm}$, and 30 to $60 \mathrm{~cm}$ along the field diagonals using a hand-operated soil core sampler. Soil core samples were homogenized by depth and sent to the soil-testing laboratory at B \& $\mathrm{C}$ Ag Consulting (Billings, MT) for soil nutrient analysis. The physical characteristics and nutrient analysis of the combined top soil layer $(0$ to $60 \mathrm{~cm}$ depth) has been summarized in Table 1 . Based on the soil analysis, all test plots were fertilized with phosphorus and potash as per the MSU recommendations for barley production (Jacobsen et al. 2005). The fertilizer mixture BEST PHOS $^{\circledR}$ Micro-Pellets 11-55-0 (N-P-K) (BEST ${ }^{\circledR}$ Fertilizer; JR Simplot, P.O. Box 198, Lathrop, CA 95330) was used as a source of phosphorus. Available soil $\mathrm{N}$ at the study site was determined in the top $60 \mathrm{~cm}$ soil depth, and the target $\mathrm{N}$ rate for each plot was adjusted according to the residual $\mathrm{N}$ analysis and the $\mathrm{N}$ credit from the BEST PHOS $^{\circledR}$ Micro-Pellets fertilizer mixture used. Urea was applied as the main source of fertilizer $\mathrm{N}$ and was evenly broadcast in the plots using a ground-driven fertilizer drop spreader and incorporated into the soil by a secondary tillage operation. The major broadleaf weeds in irrigated barley production in this region, including kochia, common lambsquarters, wild buckwheat, and redroot pigweed were investigated. Each year, fully matured, intact seeds of the target weeds collected from a naturally infested area at the MSU-SARC research farm were used. Seeds of all weed species were uniformly broadcast in the test plots and incorporated into the soil with the fertilizer $\mathrm{N}$

Table 1. Nutrient analysis of the top soil layer $(0-60 \mathrm{~cm}$ depth) from the field site at the Montana State University Southern Agricultural Research Center near Huntley, MT. ${ }^{\mathrm{a}, \mathrm{b}}$

\begin{tabular}{|c|c|c|c|c|c|c|c|c|c|c|}
\hline Year & Nitrate N & Olsen P & Available K & Sulfate $S$ & Zinc & Iron & Copper & Manganese & $\mathrm{OM}$ & $\mathrm{pH}$ \\
\hline & & & & $-\mathrm{mg} \mathrm{kg}^{-}$ & & & & & $\%$ & \\
\hline 2011 & 14.7 & 7.0 & 321.3 & 45.3 & 0.8 & 19.7 & 1.0 & 5.1 & 2.8 & \\
\hline 2012 & 15.0 & 7.3 & 292.2 & 40.9 & 0.9 & 16.2 & 1.3 & 7.9 & 2.7 & 8.1 \\
\hline 2013 & 16.8 & 7.5 & 305.1 & 42.5 & 0.7 & 14.5 & 1.1 & 5.3 & 2.8 & 8.0 \\
\hline
\end{tabular}

\footnotetext{
${ }^{a}$ Each year, soil samples were collected with hand-operated soil core samplers before barley planting. Number of soil samples (n) collected along the field diagonals in 2011, 2012, and 2013 were 25, 30 and 30, respectively.

b Abbreviation: OM, organic matter.
} 
before barley planting. Barley variety "AC Metcalfe" was planted with $18 \mathrm{~cm}$ row spacing on April 24, 2011, April 19, 2012, and April 21, 2013. Barley seedlings emerged 5 to $7 \mathrm{~d}$ after planting. Barley plots were surface (furrow) irrigated as per the local standards. Grass weeds present at the test site were controlled by a POST application of pinoxaden (Axial $\left.\mathrm{XL}^{\circledR}\right)$ at $60 \mathrm{~g} \mathrm{ha}^{-1}$. Broadleaf weeds other than the target weed species in the test plots were removed with hand weeding on an as-needed basis, starting $1 \mathrm{wk}$ after planting.

Treatments were arranged as a factorial in a randomized complete block design with four replications. Each plot was $1.5 \mathrm{~m}$ wide by $10 \mathrm{~m}$ long. The three factors in the study were $\mathrm{N}$ rate: 56 (low), 112 (medium), and 168 (high) $\mathrm{kg} \mathrm{ha}^{-1}$; barley seeding rate: 38,76 , and $152 \mathrm{~kg} \mathrm{ha}^{-1}$; and weed removal timing: nontreated, season-long weedfree, weed removal at the 3- to 4-leaf (LF) stage of barley (representing early-season herbicide application timing), and weed removal at the 8- to l0-LF stage of barley (representing late-season herbicide application timing). The two weed removal treatments were obtained by applying bromoxynil plus MCPA at the recommended rate at the 3- to 4-LF stage and 8- to 10-LF stage of barley, respectively, and by hand weeding thereafter. The season-long weed-free plots were maintained by hand weeding on an as-needed basis starting from barley planting though harvest.

Two $1 \mathrm{~m}^{2}$ quadrats were established at the center of each plot to measure total weed density and biomass. The total weed density in each plot was measured at the 3- to 4-LF stage of barley. At each weed removal timing (3- to 4-LF stage of barley, 8- to 10-LF stage of barley, or at barley harvest for nontreated plots), all weeds (kochia, redroot pigweed, common lambsquarters, and wild buckwheat) within the two $1-\mathrm{m}^{2}$ quadrats in a plot were harvested at the soil surface as a composite sample and placed in a paper bag. The samples were oven dried at $60 \mathrm{C}$ for $3 \mathrm{~d}$ to determine the total weed biomass per square meter (on the basis of dry weight) at each weed removal timing.

Barley growth parameters were measured within two 1-m lengths of row in the center of each plot. Barley density was measured $10 \mathrm{~d}$ after emergence. Barley plant height (five randomly selected plants within the sampling area) was measured at heading. To determine the aboveground barley biomass, plants within the two 1-m lengths of row were harvested at the heading stage. At maturity, barley was harvested using a plot combine, and grain yields were recorded. Barley grain yields $\left(\mathrm{kg} \mathrm{ha}^{-1}\right)$ were adjusted to $12.5 \%$ moisture content ( $\mathrm{McVay}$ et al. 2009). Test weight $\left(\mathrm{kg} \mathrm{m}^{-3}\right)$ and percent grain moisture content were obtained for each plot using a Dickey-john GAC 2100 grain analyzer (Dickeyjohn, Auburn, IL 62615). Grain protein (\%) was determined on a $100 \%$ dry matter basis. Percent plump and thin kernels were determined by measuring the amount of a $100 \mathrm{~g}$ subsample retained above a 6/64 inch slotted screen and passing through a 5.5/64 inch slotted screen, respectively, following 30 oscillations on a sieve shaker.

Greenhouse Experiments. Greenhouse experiments were conducted in 2011 and 2012 at the MSU-SARC near Huntley, MT, using two grass weed species (wild oat and green foxtail) and two broadleaf weed species (kochia and Russian thistle). The selective POST herbicides labeled in cereal crops (wheat or barley) for control of grass and broadleaf weed species were included, along with glyphosate and glufosinate. The selected herbicides belong to different herbicide groups and sites of action, and $\mathrm{N}$ is involved directly or indirectly in the biochemical pathways that some of these herbicides target in plants (Mithila et al. 2008; Vencill 2002). For instance, $\mathrm{N}$ is involved in the amino acid synthesis pathway (target for acetolactate synthase [ALS] inhibitors and glyphosate), the ammonia detoxification pathway (target for glufosinate), and the chlorophyll/carotenoid synthesis pathway (target for bromoxynil and pyrasulfotole) (Vencill 2002). Therefore, it was hypothesized that varying levels of soil $\mathrm{N}$ could alter the efficacy of these herbicides on the target weed species.

Plastic pots of $0.5 \mathrm{~L}$ capacity were filled with the soil collected from a field at the experimental site, with soil properties as previously described. The field soil from 0 to $30 \mathrm{~cm}$ depth contained $7.2 \mathrm{mg} \mathrm{NO} 3,5.3 \mathrm{mg} \mathrm{P}_{2} \mathrm{O}_{5}$, and $400 \mathrm{mg} \mathrm{K}_{2} \mathrm{O} \mathrm{kg}^{-1}$ soil as per the nutrient analysis. Prior to pot filling, the soil was fertilized with $0.30 \mathrm{~g}$ $\mathrm{KH}_{2} \mathrm{PO}_{4}, 0.25 \mathrm{~g} \mathrm{MgSO}_{4}, 0.50 \mathrm{~g} \mathrm{CaSO}_{4}, 0.02 \mathrm{~g}$ $\mathrm{MnSO}_{4}$, and $0.04 \mathrm{~g} \mathrm{CuSO}_{4} \mathrm{~kg}^{-1}$ of soil. Two filter papers (Whatman ${ }^{\circledR}$, grade 2; Sigma-Aldrich, St. Louis, MO 63178) were placed at the bottom of each pot to prevent nutrient leaching from the holes (Fang et al. 2010). Two N treatments designated as either "low" $\left(56 \mathrm{~kg} \mathrm{~N} \mathrm{ha}^{-1}\right)$ or "high" $\left(168 \mathrm{~kg} \mathrm{~N} \mathrm{ha}^{-1}\right)$ were applied, with ammonium nitrate (Cathcart et al. 2004) as the source of added N (Granular/Certified ACS; Fisher Scientific, Fair Lawn, NJ 07410). Based on residual soil $\mathrm{N}$, the desired amount of ammonium nitrate was calculated on a volumetric basis, and thoroughly mixed 
into the soil. Four to five seeds of each target weed species were used; seeds of wild oat and green foxtail were planted $1.5 \mathrm{~cm}$ deep into the soil, and kochia and Russian thistle seeds were planted on the soil surface. After emergence, weeds were thinned to approximately 2 plants $\operatorname{pot}^{-1}$ for wild oat and green foxtail, and 1 plant pot $^{-1}$ for kochia and Russian thistle. The greenhouse was maintained at $25 / 23 \pm 3 \mathrm{C}$ day/night temperatures and 16/8 h day/night photoperiods supplemented with metal halide lamps $\left(400 \mu \mathrm{mol} \mathrm{m} \mathrm{s}^{-1}\right)$.

For each weed species, treatments were arranged as a factorial in a randomized complete block design with five replications. The two factors in the study were (1) $\mathrm{N}$ rate: 56 and $168 \mathrm{~kg} \mathrm{~N} \mathrm{ha}^{-1}$; and (2) herbicide rate: four rates representing from 12.5 to $100 \%$ of a recommended field rate plus a nontreated control (Table 2). Herbicides were applied when grass weeds reached the 3- to 4-LF stage, which corresponded to a broadleaf weed stage of approximately 8 to $10 \mathrm{~cm}$ height. Herbicide treatments were applied using a stationary cabinet spray chamber equipped with a flat-fan nozzle tip (TeeJet 8001XR; Spraying Systems, Wheaton, IL) calibrated to deliver $94 \mathrm{~L} \mathrm{ha}^{-1}$ of spray solution at $276 \mathrm{kPa}$. After the herbicide treatment, plants were returned to the greenhouse and watered (approximately $100 \mathrm{ml} \mathrm{pot}^{-1}$ ) as and when needed to avoid moisture stress. The percent control of each target weed species was visually assessed at 1,2 , and 3 wk after treatment (WAT). Plants were harvested at the soil level 3 WAT and dried in paper bags at $60 \mathrm{C}$ for $3 \mathrm{~d}$ to determine the shoot dry weight (g plant $\left.{ }^{-1}\right)$. The shoot dry weight of a treated plant was expressed as a percentage of the nontreated control.

Statistical Analyses. Field data were subjected to ANOVA using the PROC MIXED procedure in SAS (Statistical Analysis Systems ${ }^{\circledR}$, version 9.2; SAS Institute, SAS Campus Drive, Cary, NC 27513). Variances were divided into fixed effects (year, $\mathrm{N}$ rate, seeding rate, weed removal timing, and their interactions) and random effects (replication and interactions involving replication) (SAS 9.2). For all data, the interaction of year by treatment was nonsignificant $(\mathrm{P}>0.05)$; therefore, data for 2011, 2012, and 2013 were pooled. Residual analysis was performed using PROC UNIVARIATE in SAS, which revealed that the distribution of residuals met

Table 2. List of herbicides tested, including their site of action, trade name, doses and adjuvants, and target weed species in the dose-response studies conducted in the greenhouse in 2011 and 2012.

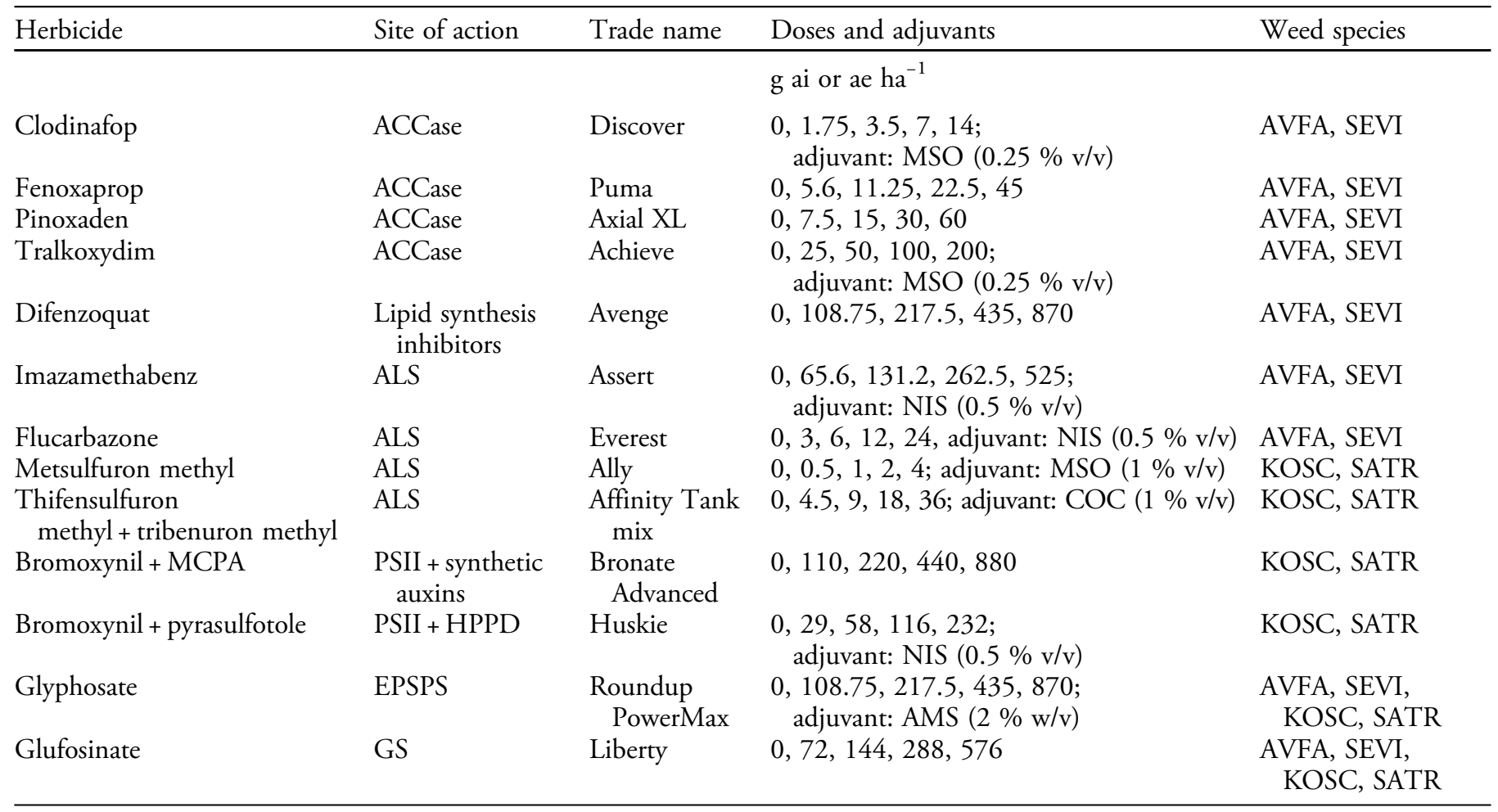

${ }^{a}$ Abbreviations: ACCase, acetyl CoA carboxylase; ALS, acetolactate synthase; PSII, photosystem II; HPPD, 4-hydroxyphenylpyruvate-dioxygenase; EPSPS, 5-enolpyruvyl-shikimate-3-phosphate synthase; GS, glutamine synthetase; MSO, methylated seed oil; NIS, nonionic surfactant; COC, crop oil concentrate; AMS, ammonium sulfate; AVFA, Avena fatua; SEVI, Setaria viridis; KOSC, Kochia scoparia; SATR, Salsola tragus. 
the criteria for analysis of variance (ANOVA). Means for the main effects of $\mathrm{N}$ rate, barley seeding rate, weed removal timing, and their interactions (when significant) were separated by Fisher's Protected LSD test at $\mathrm{P}<0.05$ using the PDMIX800 macro in SAS (Saxton 1998). A three-parameter log-logistic model (Equation 1) was fitted to estimate the effect of increasing duration of weed interference (weeks after barley emergence [WAE]) on the percentage grain yield loss of barley at each $\mathrm{N}$ rate using the drc package in $\mathrm{R}$ software (Knezevic and Datta 2015):

$$
Y=d / 1+\exp \{b[\log t-\log e]\}
$$

where $Y$ is the barley grain yield expressed as a percentage of season-long weed-free yield, $d$ is the upper limit of the curve, $t$ is the time expressed as WAE, $b$ is the slope of the curve at the inflection point, and $e$ is the number of weeks after emergence when the inflection point occurs, giving a 50\% response between the upper and lower limits (referred to as $\mathrm{ED}_{50}$ ). A lack-of-fit test was performed to compare the regression model (Equation 1) with the ANOVA to determine whether the selected model was an appropriate fit to the data. The CTWR for each $\mathrm{N}$ rate was determined from the fitted model using 5 and $10 \%$ levels of acceptable yield losses (AYL) (Knezevic and Datta 2015). The estimated CTWR values from the fitted model (based on 5 and $10 \%$ AYL) were compared among $\mathrm{N}$ rates using an approximate $t$-test (Knezevic et al. 2007).

For greenhouse experiments, data on shoot dry weights were subjected to ANOVA using the PROC MIXED procedure in SAS for testing the significance of experimental run, replication, treatment $(\mathrm{N}$ rate or herbicide dose [D]), and their interactions. Data were pooled across the experimental runs on the basis of nonsignificant run by treatment interaction $(\mathrm{P}>0.05)$. The shoot dry weight of each weed species was regressed against herbicide doses using the three-parameter log-logistic model (Equation 2) (Knezevic et al. 2007).

$$
Y=D / 1+\exp \{B[\log X-\log E]\}
$$

where $Y$ refers to shoot dry weight (\% of nontreated), $D$ is the upper limit, $B$ is the slope, $E$ is the herbicide dose required for $50 \%$ reduction in shoot dry weight referred to as $\mathrm{GR}_{50}$, and $X$ is the herbicide dose. A lack-of-fit test $(P>0.05)$ showed the accuracy of the fitted models for the weed species or herbicides tested. Parameter estimates, standard errors, and $95 \%$ confidence intervals (both lower and upper) for $\mathrm{GR}_{50}$ values were determined from the fitted models using the drc package in $\mathrm{R}$ software (Knezevic et al. 2007).

\section{Results and Discussion}

Field Study. Among all four weed species, kochia was the first to emerge in the barley plots each year. Kochia emergence timing coincided with the barley emergence date ( 5 to $7 \mathrm{~d}$ after barley planting). The mean air temperature was $10 \mathrm{C}$ at the time of kochia emergence each year (Figure 1). The emergence of three other weed species, including common lambsquarters, redroot pigweed, and wild buckwheat, occurred 10 to $12 \mathrm{~d}$ after kochia emergence in all 3 yr. The total weed density at the 3- to 4-LF stage of barley ranged from 98 to 115 plants $\mathrm{m}^{-2}$ during all 3 yr (unpublished data).

The total weed biomass was greatest in the nontreated plots (Table 3). Delaying the weed removal timing to the 8- to 10 -LF stage of barley resulted in 2.1- to 3.5-fold greater total weed biomass compared with the 3- to 4-LF stage timing across 56 to $168 \mathrm{~kg} \mathrm{~N} \mathrm{ha}^{-1}$ rates. There was a significant interaction of $\mathrm{N}$ rate by weed removal timing on the total weed biomass; the differences in weed biomass across $\mathrm{N}$ rates occurred only when weeds were not removed (nontreated plots). In nontreated plots, kochia, common lambsquarters, redroot pigweed, and wild buckwheat under the low $\mathrm{N}$ rate $\left(56 \mathrm{~kg} \mathrm{ha}^{-1}\right)$ accumulated a total of $487 \mathrm{~g} \mathrm{~m}^{-2}$ of biomass, which was higher than the 319 and $269 \mathrm{~g} \mathrm{~m}^{-2}$ of biomass accumulated under medium $\left(112 \mathrm{~kg} \mathrm{ha}^{-1}\right)$ and high $\left(168 \mathrm{~kg} \mathrm{ha}^{-1}\right) \mathrm{N}$ rates, respectively.

Barley plant height was only affected by the main effect of $\mathrm{N}$ rate. Averaged across seeding rates and

Table 3. Interaction of $\mathrm{N}$ rate and weed removal timing on total weed biomass in barley averaged across seeding rates and three

\begin{tabular}{|c|c|c|c|}
\hline \multirow{3}{*}{ Weed removal timing } & \multicolumn{3}{|c|}{ Total weed biomass } \\
\hline & \multicolumn{3}{|c|}{ Applied $\mathrm{N}$ rate $\mathrm{kg} \mathrm{ha}^{-1}$} \\
\hline & 56 & 112 & 168 \\
\hline & - & $\mathrm{g} \mathrm{m}^{-2}$ & {[} \\
\hline $\begin{array}{l}\text { Weeds removed at 3- to 4-LF barley } \\
\text { Weeds removed at } 8 \text { - to } 10 \text {-LF barley } \\
\text { Nontreated }\end{array}$ & $\begin{aligned} 43 \mathrm{e} \\
150 \mathrm{~d} \\
487 \mathrm{a}\end{aligned}$ & $\begin{array}{rl}56 & \mathrm{e} \\
132 & \mathrm{~d} \\
319 & \mathrm{~b}\end{array}$ & $\begin{array}{rl}59 & \mathrm{e} \\
127 \mathrm{~d} & \\
269 \mathrm{c} & \end{array}$ \\
\hline
\end{tabular}
growing seasons (2011-2013). ${ }^{\mathrm{a}}$

${ }^{a}$ Means with the same letter are not significantly different based on Fisher's protected LSD test at $\mathrm{P}<0.05$. 


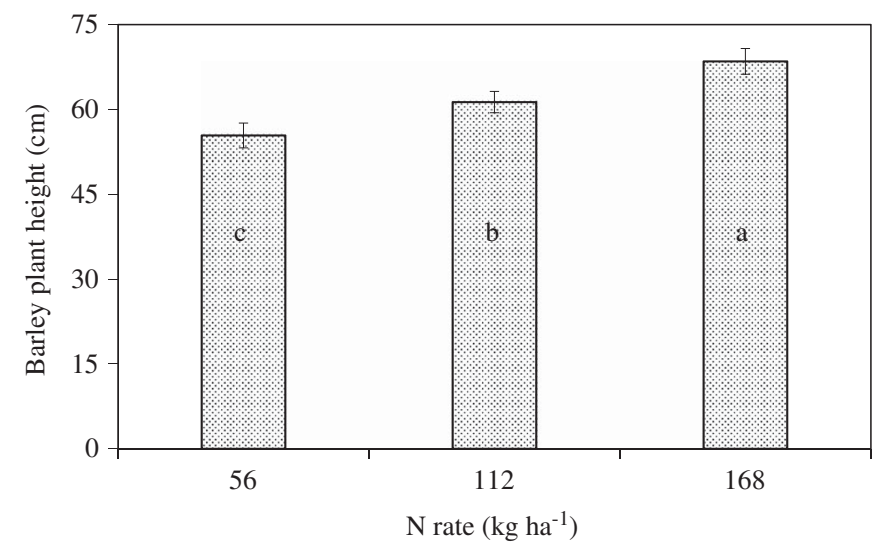

Figure 2. Effect of increasing $\mathrm{N}$ rate on barley plant height averaged across the three growing seasons (2011-2013). Vertical bars represent the standard error of the mean. Means with the same letter are not significantly different based on Fisher's protected LSD at $\mathrm{P}<0.05$.

weed removal timings, the barley plant height was 19 and $11 \%$ less under low $\left(56 \mathrm{~kg} \mathrm{ha}^{-1}\right)$ and medium $\left(112 \mathrm{~kg} \mathrm{ha}^{-1}\right) \mathrm{N}$ rates, respectively, compared with the high $\mathrm{N}$ rate $\left(168 \mathrm{~kg} \mathrm{ha}^{-1}\right.$ ) (Figure 2).

Barley density was only influenced by the main effect of seeding rate. Averaged across $\mathrm{N}$ rates and weed removal timings, barley density was 50 and $28 \%$ less under low $\left(38 \mathrm{~kg} \mathrm{ha}^{-1}\right)$ and medium $\left(76 \mathrm{~kg} \mathrm{ha}^{-1}\right)$ seeding rates, respectively, compared with the high seeding rate $\left(152 \mathrm{~kg} \mathrm{ha}^{-1}\right)$ (Figure 3A).

The aboveground barley biomass was influenced by the main effects of $\mathrm{N}$ rate, seeding rate, and weed removal timing, and the interaction of $\mathrm{N}$ rate by weed removal timing. Results indicated that increasing the barley seeding rate from 38 to $152 \mathrm{~kg}$ seeds $\mathrm{ha}^{-1}$ increased the aboveground barley biomass by $13 \%$ (Figure 3B). Delaying the weed removal timing to the 8- to 10-LF stage of barley reduced barley biomass compared with the 3- to 4-LF stage timing, irrespective of $\mathrm{N}$ rate (Table 4). Barley biomass was least at the $56 \mathrm{~kg} \mathrm{~N} \mathrm{ha}^{-1}$ rate. Increasing the $\mathrm{N}$ rate from 112 to $168 \mathrm{~kg} \mathrm{ha}^{-1}$ did not further increase barley biomass in the season-long weed free or 3- to 4-LF weed removal timing plot; nevertheless, the difference was evident when the weed removal timing was delayed to the 8-to 10-LF stage or in the nontreated plots.

Barley grain yield was also influenced by the main effects of $\mathrm{N}$ rate, seeding rate, and weed removal timing, and the interaction of $\mathrm{N}$ rate by weed removal timing. Results indicated that increasing the barley seeding rate from 38 to $152 \mathrm{~kg} \mathrm{ha}^{-1}$ increased the barley grain yield by $29 \%$ (Figure 3C). The interaction of $\mathrm{N}$ rate by weed removal timing on
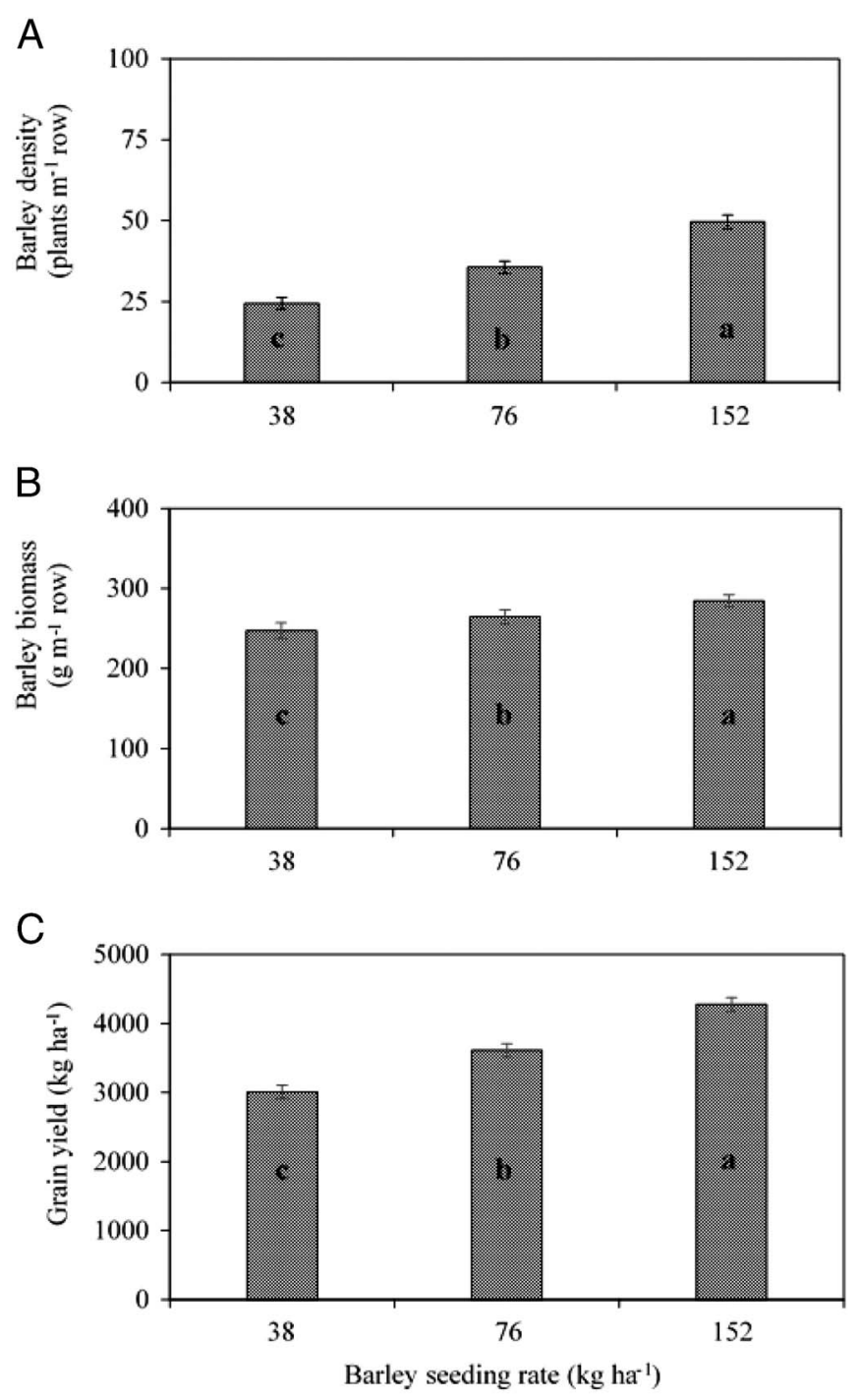

Figure 3. Effect of increasing seeding rate on barley plant density (A), aboveground biomass (B), and grain yield (C) averaged across the three growing seasons (2011-2013). Vertical bars represent the standard error of the mean. Means with the same letter are not significantly different based on Fisher's protected LSD at $\mathrm{P}<0.05$.

barley grain yield is discussed below in the context of CTWR.

Averaged across the $3 \mathrm{yr}$, the weed removal timing or the duration of weed interference (weeks after barley emergence) influenced the percentage barley grain yield loss. The lack-of-fit test revealed that the selected model (Equation 1) was appropriate for describing the relationship between barley grain yield loss and duration of weed interference at each $\mathrm{N}$ rate (Table 5). Barley grain yield loss increased with a delay in weed removal timing, but the magnitude of the yield loss was $\mathrm{N}$ dependent, with potentially greater yield loss under low vs. medium or high $\mathrm{N}$ rate. 
Table 4. Interaction of $\mathrm{N}$ rate and weed removal timing on the aboveground barley biomass averaged across seeding rates and three growing seasons (2011-2013). ${ }^{\mathrm{a}}$

\begin{tabular}{|c|c|c|c|}
\hline \multirow[b]{3}{*}{ Weed removal timing } & \multicolumn{3}{|c|}{ Barley biomass } \\
\hline & \multicolumn{3}{|c|}{ Applied $\mathrm{N}$ rate $\mathrm{kg} \mathrm{ha}^{-1}$} \\
\hline & 56 & 112 & 168 \\
\hline & & $\mathrm{g} \mathrm{m}^{-2}$ & \\
\hline Season-long weed free & $288 \mathrm{~b}$ & 301 a & $307 \mathrm{a}$ \\
\hline Weeds removed at 3- to 4-LF barley & $275 \mathrm{c}$ & $285 \mathrm{~b}$ & $291 \mathrm{~b}$ \\
\hline Weeds removed at 8 - to 10 -LF barley & $246 \mathrm{e}$ & $258 \mathrm{~d}$ & $269 \mathrm{c}$ \\
\hline Nontreated & $235 \mathrm{f}$ & $256 \mathrm{~d}$ & $266 \mathrm{c}$ \\
\hline
\end{tabular}

${ }^{a}$ Means with the same letter are not significantly different based on Fisher's protected LSD test at $\mathrm{P}<0.05$.

The CTWR in the current study was determined based on AYL levels of 5 and 10\%. These two levels of AYL were selected to allow barley growers to make adjustments in weed management decisions (Knezevic and Datta 2015). The adjustment in AYL depends on the cost of weed control, commodity price, and expected returns from the weed control practices (Knezevic et al. 2002; Knezevic and Datta 2015). The CTWR for the selected broadleaf weed species to prevent 5 and 10\% AYL of barley grain was 3.2 and 5.9 wk after barley emergence (WAE) under low $\mathrm{N}$ rate, compared with 4.5 and 7.8 WAE under medium $\mathrm{N}$ rate and 4.7 and 8.1 WAE under high $\mathrm{N}$ rate, respectively (Table 5 ).

Barley grain quality attributes, including kernel plumpness and percentage of thin kernels, were affected only by weed removal timing. Averaged across $\mathrm{N}$ and seeding rates, the percentage of plump kernels was higher in season-long weed free and 3- to 4-LF weed removal timing compared with the nontreated plots (unpublished data). Nontreated plots had the highest percentage of thin kernels among all weed removal timings (unpublished data).

The interaction of $\mathrm{N}$ rate by barley seeding rate influenced the percentage of plump kernels and test weight. Under the low $\mathrm{N}$ rate $\left(56 \mathrm{~kg} \mathrm{ha}^{-1}\right)$, the kernel plumpness did not differ between the seeding rates of 38 and $76 \mathrm{~kg} \mathrm{ha}^{-1}$ and averaged $81 \%$ (Figure 4A); however, a further increase in the seeding rate to $152 \mathrm{~kg} \mathrm{ha}^{-1}$ reduced kernel plumpness. At medium $\left(112 \mathrm{~kg} \mathrm{ha}^{-1}\right)$ and high (168 kg $\left.\mathrm{ha}^{-1}\right) \mathrm{N}$ rates, barley seeding rate did not affect the kernel plumpness. Barley test weight was reduced from 546 to $534 \mathrm{~kg} \mathrm{~m}^{-3}$ with an increase in the seeding rate from 38 to $76 \mathrm{~kg} \mathrm{ha}^{-1}$ under the low $\mathrm{N}$ rate (Figure $4 \mathrm{~B}$ ). Previous researchers also reported that increasing barley seeding rates from 45 to $182 \mathrm{~kg} \mathrm{ha}^{-1}$ reduced kernel plumpness and kernel weight (McKenzie et al. 2005; O'Donovan et al. 2012). Nevertheless, under the medium $N$ rate, barley test weight increased slightly from 547 to $554 \mathrm{~kg} \mathrm{~m}^{-3}$, with an increase in the seeding rate from 38 to $76 \mathrm{~kg} \mathrm{ha}^{-1}$; no further increase in the test weight was observed at the seeding rate of $152 \mathrm{~kg}$ $\mathrm{ha}^{-\mathrm{P}}$. Seeding rate did not affect the barley test weight under high $\mathrm{N}$. The barley protein (\%) was influenced only by the main effect of $\mathrm{N}$ rate. Increasing the $\mathrm{N}$ rate from 56 to $168 \mathrm{~kg} \mathrm{ha}^{-1}$ increased the barley protein from 11 to $15 \%$ (Figure 5). The acceptable protein content in malting barley is 7.5 to $14 \%$ (McVay et al. 2009). A lower protein concentration in barley grain is

Table 5. Parameter estimates for the three-parameter log-logistic model (Equation 1) to determine the effect of increasing duration of weed interference (WAE) on percentage grain yield loss at the three $\mathrm{N}$ rates based on 5 and $10 \%$ AYL levels. The model was fitted to barley grain yield (\% of season-long weed-free) as a function of increasing duration of broadleaf weed interference (WAE). ${ }^{\text {a-d }}$

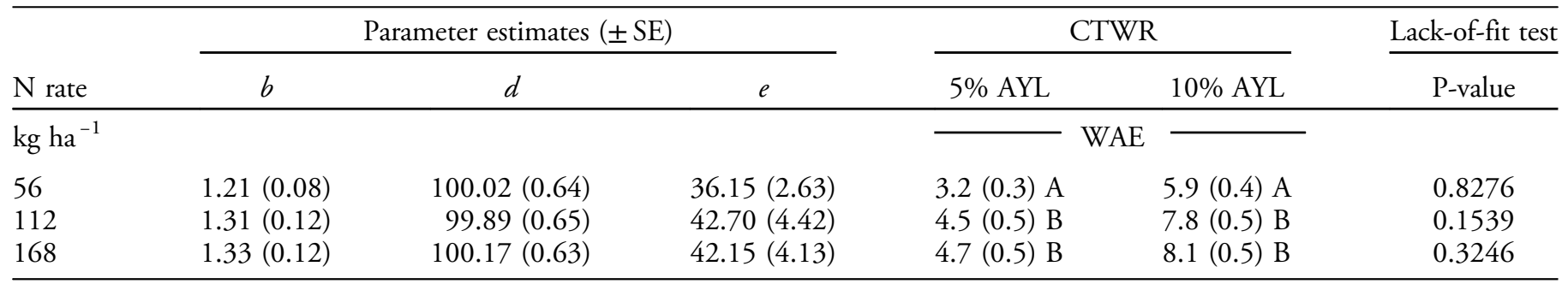

\footnotetext{
${ }^{a}$ Three-parameter $\log$-logistic model: $\left.Y=d / 1+\exp \{b[\log t-\log e)]\right\}$, where $Y$ is the percentage loss of barley grain yield, $t$ is the time expressed as WAE, $b$ is the slope of the curve at the inflection point, $d$ is the upper limit of the curve, and $e$ is the number of WAE when the inflection point occurs.

${ }^{\mathrm{b}}$ Abbreviations: CTWR, critical timing of weed removal; AYL, acceptable yield loss; WAE, wk after barley emergence.

${ }^{\mathrm{c}}$ The estimated CTWR values at 5 and 10\% AYL (within a column) followed by the same uppercase letter are not significantly different based on approximate $t$-test (Knezevic et al. 2007).

${ }^{\mathrm{d}}$ A lack-of-fit test comparing the log-logistic model to ANOVA was conducted to determine whether the model was an appropriate fit to the grain yield data (Knezevic et al. 2007).
}

196 - Weed Science 65, January-February 2017 

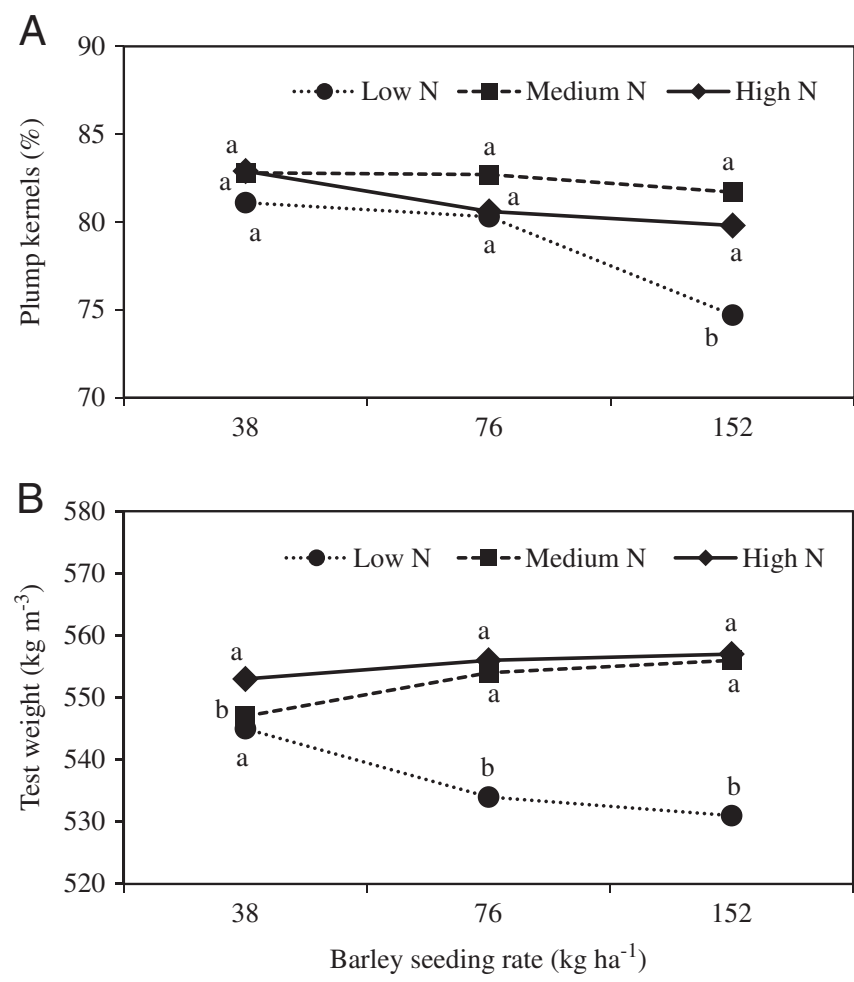

Figure 4. Effects of $\mathrm{N}$ rate and seeding rate on kernel plumpness and test weight of barley averaged across the three growing seasons. Means across seeding rates for each $\mathrm{N}$ level with the same letter are not significantly different based on Fisher's protected LSD at $\mathrm{P}<0.05$.

recommended for improved endosperm, uniform kernels, and a better-quality malt (McKenzie et al. 2005, O’Donovan et al. 2012).

Greenhouse Study. The main effects of $\mathrm{N}$ rate and herbicide dose (D) influenced shoot dry weights (\% of nontreated) of wild oat and green foxtail

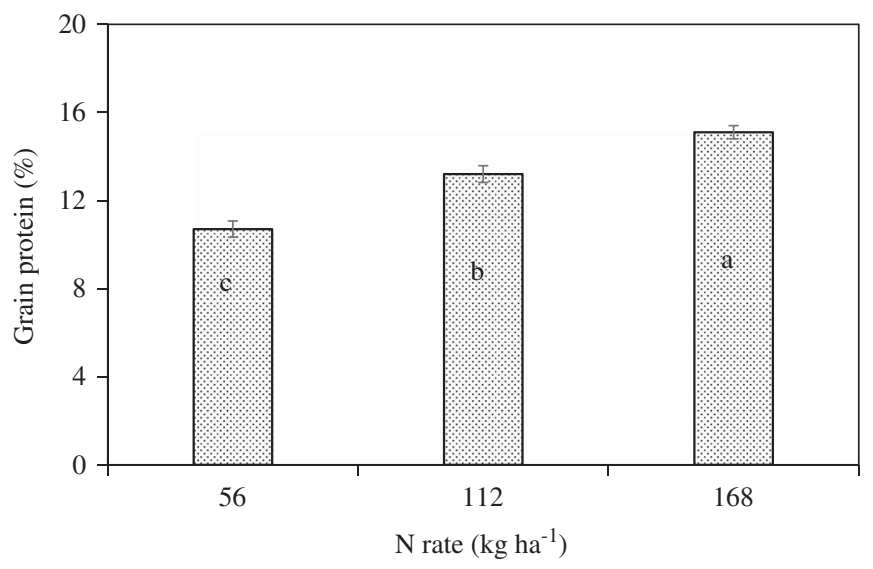

Figure 5. Effect of $\mathrm{N}$ rate on barley grain protein averaged across the three growing seasons (2011-2013). Vertical bars represent standard error of the mean. Means with the same letter are not significantly different based on Fisher's protected LSD at $\mathrm{P}<0.05$. for all herbicide-species combinations tested. The interaction of $\mathrm{N}$ by $\mathrm{D}$ was also evident for majority of the tested herbicide-species combinations.

Based on the fitted model, the $\mathrm{GR}_{50}$ values of wild oat plants treated with tralkoxydim and pinoxaden were 1.7 - and 1.8 -fold, respectively, greater under the low $\mathrm{N}\left(56 \mathrm{~kg} \mathrm{ha}^{-1}\right)$ compared with the high $\mathrm{N}$ rate $\left(168 \mathrm{~kg} \mathrm{ha}^{-1}\right)$ (Table 6). Similarly, the $\mathrm{GR}_{50}$ values of green foxtail treated with tralkoxydim and pinoxaden were 1.6- and 1.5fold, respectively, greater under low vs. high $\mathrm{N}$ soil. The $\mathrm{GR}_{50}$ values for wild oat were 2.6- and 1.5-fold greater at low vs. high $\mathrm{N}$ rate when treated with flucarbazone and glyphosate, respectively. Similarly, the efficacy of clodinafop, fenoxaprop, and glufosinate was greater on green foxtail plants grown under high $\mathrm{N}$ soil, with 27 to $50 \%$ lower $\mathrm{GR}_{50}$ values at the high compared with the low $\mathrm{N}$ rate.

The effect of $\mathrm{N}$ rate on the efficacy of nicosulfuron (ALS inhibitor), glyphosate, fluazifop, and diclofop (same herbicide group as clodinafop and fenoxaprop) has previously been reported on grass weed species, including green foxtail and oat. Dickson et al. (1990) found that fluazifop $\left(0.25 \mathrm{~kg} \mathrm{ha}^{-1}\right)$ and glyphosate $\left(0.18 \mathrm{~kg} \mathrm{ha}^{-1}\right)$ were more effective in preventing seed head formation of oats grown under 200 (high) vs. 0 (low) $\mathrm{kg}$ added $\mathrm{N} \mathrm{ha}^{-1}$. Similarly, the efficacy of diclofop-methyl on oats was greater at the high compared with the low $\mathrm{N}$ soil (Andrews et al. 1989). Cathcart et al. (2004) reported that the amount of nicosulfuron required for $50 \%$ shoot dry weight reduction of green foxtail was 6-fold greater at low $(0.7 \mathrm{mM})$ compared with high $(7.7 \mathrm{mM}) \mathrm{N}$ rate in a growth chamber study.

For all herbicides tested, the main effects of $\mathrm{N}$ rate and herbicide dose (D) influenced shoot dry weights of kochia and Russian thistle for the majority of the herbicide-species combinations tested. The $\mathrm{N}$ by $\mathrm{D}$ interaction was evident for kochia or Russian thistle treated with thifensulfuron methyl + tribenuron methyl, metsulfuron methyl, or bromoxynil + pyrasulfotole.

Based on the fitted log-logistic model, the $\mathrm{GR}_{50}$ value of thifensulfuron-methyl + tribenuron-methyl was 2.1- and 1.6-fold greater for kochia and Russian thistle, respectively, at low $\left(56 \mathrm{~kg} \mathrm{ha}^{-1}\right)$ compared with high $\left(168 \mathrm{~kg} \mathrm{ha}^{-1}\right) \mathrm{N}$ soil (Table 7). Consistent with our findings on kochia and Russian thistle, Sønderskov et al. (2012) reported that the $\mathrm{GR}_{50}$ value of tribenuronmethyl-treated scentless chamomile [Tripleurospermum inodorum (L.) Sch. Bip.], another broadleaf weed, declined from 0.24 to $0.14 \mathrm{~g} \mathrm{ha}^{-1}$ with an increase in the soil $\mathrm{N}$ rate from 0 to $120 \mathrm{~kg} \mathrm{ha}^{-1}$. Similarly, the $\mathrm{GR}_{50}$ value of metsulfuron-methyl for kochia grown 
Table 6. Regression parameters from the three-parameter log-logistic model used to fit shoot dry weights (\% of nontreated) of herbicide-treated wild oat (AVFA) and green foxtail (SEVI) grown under low $\left(56 \mathrm{~kg} \mathrm{ha}^{-1}\right)$ or high $\left(168 \mathrm{~kg} \mathrm{ha}^{-1}\right)$ soil N. ${ }^{\mathrm{a}-\mathrm{c}}$

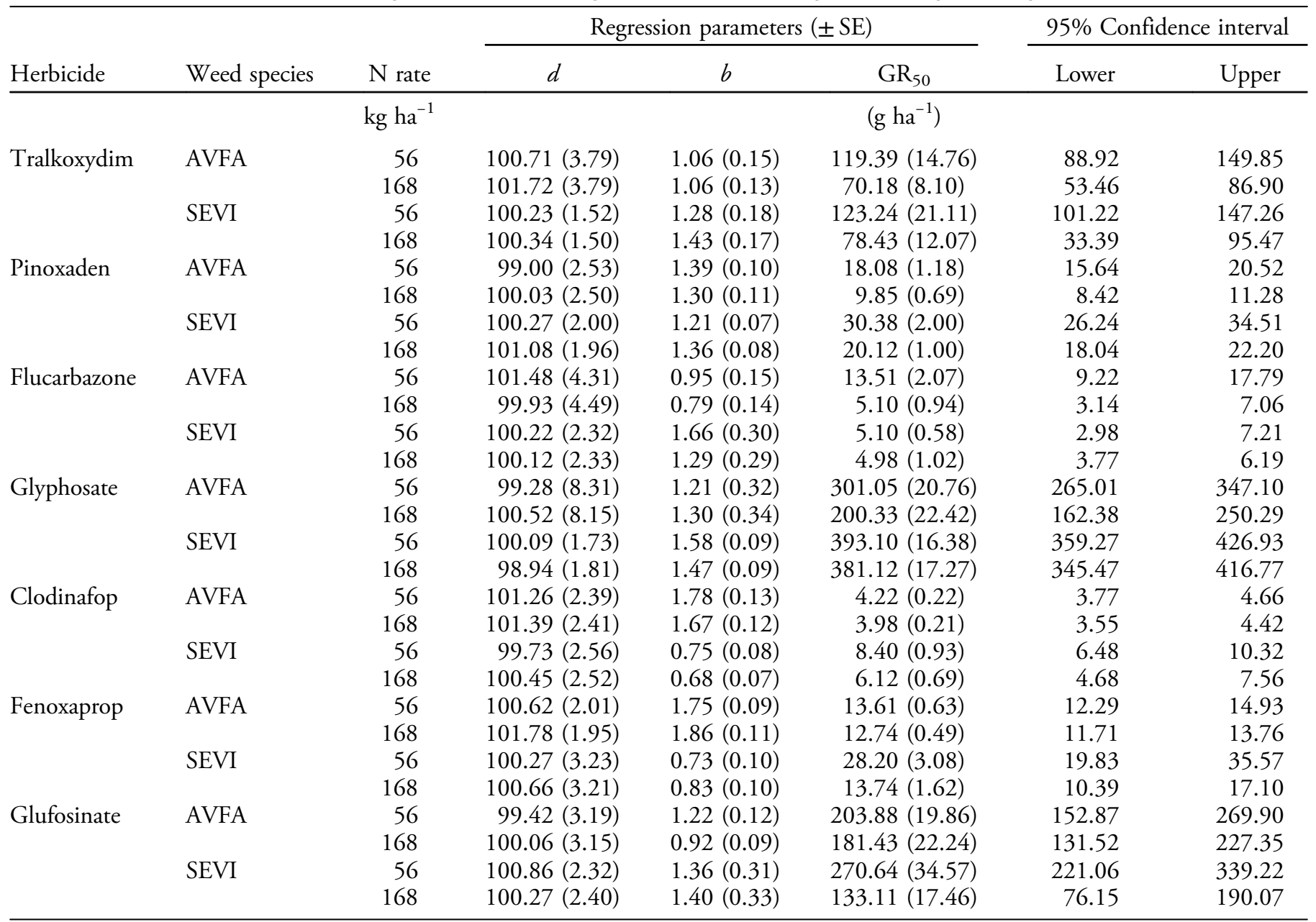

${ }^{a}$ Regression analyses were included only for those herbicide and weed species where the $\mathrm{N} \times \mathrm{D}$ interaction was significant.

${ }^{\mathrm{b}} \mathrm{GR}_{50}$ is effective dose ( $\mathrm{g}$ ai or ae ha ${ }^{-1}$ ) of herbicide required for $50 \%$ shoot dry weight reduction of wild oat or green foxtail.

${ }^{c}$ The $95 \%$ confidence intervals for each $\mathrm{GR}_{50}$ dose are included.

under low $\mathrm{N}$ was increased by 1.6-fold when compared with kochia grown under high $\mathrm{N}$ soil (Table 7). An increase in the efficacy of bromoxynil + pyrasulfotole premix on Russian thistle was also observed, with a decrease in the $\mathrm{GR}_{50}$ value from 114 to $73 \mathrm{~g} \mathrm{ha}^{-1}$ when the $\mathrm{N}$ rate was increased from 56 to $168 \mathrm{~kg} \mathrm{ha}^{-1}$.

Results from the field research highlight that increasing the barley seeding rate from 38 to $152 \mathrm{~kg}$ $\mathrm{ha}^{-1}$ increased barley plant density by $50 \%$, aboveground biomass by $13 \%$, and grain yields by $29 \%$, averaged across $\mathrm{N}$ rates and weed removal timings. The effect of high seeding rates on increased wheat and barley grain yields have previously been reported (O'Donovan et al. 2000, 2003; Yenish and Young 2004). For instance, O'Donovan et al. (2000) observed that increasing the barley seeding rate from 85 to $200 \mathrm{~kg} \mathrm{ha}^{-1}$ resulted in a $28 \%$ increase in the barley grain yield. The results from this study suggest that higher seeding rates can enhance the competitive ability of barley against kochia, common lambsquarters, wild buckwheat, and redroot pigweed, and should be utilized as an important component of IWM programs in barley production.

Consistent with our results, Alazmani (2015) reported that increasing the fertilizer $\mathrm{N}$ rate from 75 to $225 \mathrm{~kg} \mathrm{ha}^{-1}$ resulted in a $9 \%$ increase in the barley plant height. Delaying the weed removal timing from the 3- to 4-LF stage to the 8- to 10-LF stage of barley reduced barley biomass and increased weed biomass (2.1- to 3.5-fold), implying that early weed removal timing is critical to improve barley competitiveness against weeds. Evident in the nontreated plots, kochia, common lambsquarters, wild buckwheat, and redroot pigweed accumulated greater total biomass, and were at a competitive advantage under 168 compared with 112 or $56 \mathrm{~kg} \mathrm{~N} \mathrm{ha}^{-1}$ rate. This further suggests that more

198 - Weed Science 65, January-February 2017 
Table 7. Regression parameters from the three-parameter log-logistic model used to fit shoot dry weights (\% of nontreated) of herbicide-treated kochia (KOSC) and Russian thistle (SATR) grown under low $\left(56 \mathrm{~kg} \mathrm{ha}^{-1}\right)$ or high $\left(168 \mathrm{~kg} \mathrm{ha}^{-1}\right) \mathrm{N} \mathrm{soil.}^{\mathrm{a}-\mathrm{c}}$

\begin{tabular}{|c|c|c|c|c|c|c|c|}
\hline \multirow[b]{2}{*}{ Herbicide $^{a-c}$} & \multirow[b]{2}{*}{ Weed species } & \multirow[b]{2}{*}{$\mathrm{N}$ rate } & \multicolumn{3}{|c|}{ Regression parameters $( \pm \mathrm{SE})$} & \multicolumn{2}{|c|}{ 95\% Confidence interval } \\
\hline & & & $d$ & $b$ & $\mathrm{GR}_{50}$ & Lower & Upper \\
\hline & & $\mathrm{kg} \mathrm{ha}^{-1}$ & & & $\mathrm{~g} \mathrm{ha}^{-1}$ & & \\
\hline \multirow{4}{*}{$\begin{array}{l}\text { Thifensulfuron methyl + } \\
\text { tribenuron methyl }\end{array}$} & KOSC & 56 & $100.36(1.95)$ & $1.36(0.09)$ & $19.85(1.03)$ & 17.71 & 21.99 \\
\hline & & 168 & $100.30(2.04)$ & $1.25(0.08)$ & $9.45(0.51)$ & 8.37 & 10.52 \\
\hline & SATR & 56 & $99.99(1.60)$ & $0.94(0.06)$ & $20.47(1.08)$ & 18.02 & 22.93 \\
\hline & & 168 & $100.09(1.65)$ & $0.99(0.05)$ & $12.79(0.68)$ & 11.38 & 14.20 \\
\hline \multirow[t]{4}{*}{ Metsulfuron methyl } & KOSC & 56 & $99.81(2.43)$ & $1.66(0.15)$ & $2.10(0.12)$ & 1.84 & 2.35 \\
\hline & & 168 & $99.16(2.68)$ & $1.59(0.09)$ & $1.29(0.10)$ & 1.07 & 1.51 \\
\hline & SATR & 56 & $100.55(1.90)$ & $1.04(0.07)$ & $114.59(6.97)$ & 100.19 & 128.99 \\
\hline & & 168 & $100.75(1.91)$ & $1.11(0.07)$ & $73.19(4.10)$ & 64.72 & 81.67 \\
\hline
\end{tabular}

${ }^{a}$ Regression analyses were included only for those herbicides or weed species where the $\mathrm{N} \times \mathrm{D}$ interaction was significant.

${ }^{\mathrm{b}} \mathrm{GR}_{50}$ is effective dose $\left(\mathrm{g}\right.$ ai or ae ha ${ }^{-1}$ ) of herbicide required for $50 \%$ shoot dry weight reduction of kochia or Russian thistle.

${ }^{c}$ The $95 \%$ confidence intervals for each $\mathrm{GR}_{50}$ dose are included.

intensive weed management may be needed in low $\mathrm{N}$ vs. high $\mathrm{N}$ soils. The addition of $\geq 112 \mathrm{~kg} \mathrm{~N} \mathrm{ha}^{-1}$ delayed the initiation of CTWR in barley compared with the $56 \mathrm{~kg} \mathrm{~N} \mathrm{ha}^{-1}$ rate on the basis of the 5 and $10 \%$ AYL. As also reported in corn, the initiation of CTWR was delayed under high $\left(120 \mathrm{~kg} \mathrm{~N} \mathrm{ha}^{-1}\right)$ compared to low $\left(0 \mathrm{~kg} \mathrm{~N} \mathrm{ha}{ }^{-1}\right)$ or moderate $(60 \mathrm{~kg}$ $\mathrm{N} \mathrm{ha}^{-1}$ ) fertilizer $\mathrm{N}$ rate (Evans et al. 2003a, 2003b). The alteration in CTWR reported in our study highlights the significance of improving $\mathrm{N}$ management decisions in addition to early timing of weed removal to protect against grain yield losses in barley. Furthermore, increased barley seeding rates had negative effects on barley grain quality (reduced kernel plumpness and test weight) at low compared with medium or high $\mathrm{N}$ rates tested. This further indicates that optimizing fertilizer $\mathrm{N}$ inputs is crucial to take advantage of the high seeding rates on increased competitive ability of barley against weeds without adversely affecting the barley grain quality for malting purposes.

Results from the greenhouse study indicate that $\mathrm{N}$ rates influenced the herbicide efficacy tested on wild oat, green foxtail, kochia, and Russian thistle. Moreover, the effect was dependent on herbicide-weed species complex. Similar results have been reported by previous researchers for other herbicide-weed species combinations (Cathcart et al. 2004; Dickson et al. 1990; Mithila et al. 2008). The reduction in herbicide efficacy under low $\mathrm{N}$ soils, at least for systemic herbicides (glyphosate and fluazifop), was associated with reduced translocation of the herbicides out of the treated leaves (Dickson et al. 1990; Mithila et al. 2008). Furthermore, Clements et al. (1994) and Scursoni and Benech Arnold (2002) reported that differences in weed control following an herbicide treatment may affect the relative abundance of weed species, species evenness, or both in a weed community. To confirm this hypothesis, future research on the effectiveness of herbicides on individual weed species grown in mixtures under varying soil $\mathrm{N}$ levels is needed. Weed patchiness and weed control failures are important problems on farm fields, which may be explained by the reduced efficacy of herbicides under low N soils (Cathcart et al. 2004; Sønderskov et al. 2012). The physiological mechanism(s) for the increased herbicide efficacy under high vs. low $\mathrm{N}$ for the herbicide-weed species complex reported here are not known with certainty, and further research is needed to understand the mechanisms involved.

In NGP cereal production, the fertilizer $\mathrm{N}$ recommendations are currently based on soil residual nitrate and target grain yields (Jacobsen et al. 2005). Information generated from this research will help growers to consider crop-weed competition as a whole when making their agronomic and nutrient management decisions. The knowledge gained on the interaction of $\mathrm{N}$ rate with weed removal timing on weed interference in barley and on differences in weed response to herbicides under different $\mathrm{N}$ rates will aid in adoption of IWM practices to prevent weed control failures and improve grain yields in cereal production systems of this region.

\section{Acknowledgments}

We thank Nicholas Reichard and Shane Leland for their technical assistance in conducting the field experiments. Funding provided by the Montana Fertilizer Committee is greatly appreciated. 


\section{Literature Cited}

Abouziena HF, El-Karmany MF, Singh M, Sharma SD (2007) Effect of nitrogen rates and weed control treatments on maize yield and associated weeds in sandy soils. Weed Technol 21:1049-1053

Alazmani A (2015) Evaluation of yield and yield components of barley varieties to nitrogen. Intl J Agri Crop Sci 8:52-54

Andrews M, Dickson RL, Foreman MH, Dastgheib F, Field RJ (1989) The effect of different external nitrate concentrations on growth of Avena sativa L. cv. Amuri treated with diclofop-methyl. Ann Appl Biol 114:339-348

Bell AR, Nalewaja JD (1968) Competition of wild oat in wheat and barley. Weed Sci 16:505-508

Blackshaw RE, Semach G, O'Donovan JT (2000) Utilization of wheat seed rate to manage redstem filaree (Erodium cicutarium) in a zero-till cropping system. Weed Technol 14:389-396

Cathcart RJ, Chandler K, Swanton CJ (2004) Fertilizer nitrogen rate and the response of weeds to herbicides. Weed Sci 52: 291-296

Clements DR, Weise SF, Swanton CJ (1994) Integrated weed management and weed species diversity. Phytoprotection 75:1-18

Dahl GK, Dexter AG, Nalewaja JD (1982) Kochia competition and control in wheat. Pages 15-16 in Proceedings of the North Central Weed Control Conference. Indianapolis, IN: Weed Science Society of America

Derksen DA, Anderson RL, Blackshaw RE, Maxwell B (2002) Weed dynamics and management strategies for cropping systems in the Northern Great Plains. Agron J 94:174-185

Dickson RL, Andrews M, Field RJ, Dickson EL (1990) Effect of water stress, nitrogen, and gibberelic acid on fluazifop and glyphosate activity on oats (Avena sativa). Weed Sci 38: 54-61

Evans SP, Knezevic SZ, Shapiro C, Lindquist JL (2003a) Nitrogen application influences the critical period for weed control in corn. Weed Sci 51:408-417

Evans SP, Knezevic SZ, Shapiro C, Lindquist JL (2003b) Influence of nitrogen and duration of weed interference on corn growth and development. Weed Sci 51:546-556

Fang X, Turner NC, Yan G, Li F, Siddique KHM (2010) Flower numbers, pod production, pollen viability, and pistil function are reduced and flower and pod abortion increased in chickpea (Cicer arietinum L.) under terminal drought. J Exp Bot 61: $335-345$

Godara RK, William BJ, Webster EP, Griffin JL, Geaghan JP (2012) Texasweed (Caperonia palustris) interference in drillseeded rice. Weed Technol 26:356-363

Heap I (2015) International survey of herbicide resistant weeds. http://www.weedscience.org Accessed: November 9, 2015

Jacobsen J, Jackson G, Jones C (2005) Fertilizer Guidelines for Montana Crops. Bozeman, MT: Montana State University Extension Service Publication EB 161. 25 p

Jha P, Kumar V, Lim CA (2015) Variable response of kochia [Kochia scoparia (L.) Schrad] to auxinic herbicides dicamba and fluroxypyr in Montana. Can J Plant Sci 95:965-972

Knezevic SZ, Datta A (2015) The critical period for weed control: revisiting data analysis. Weed Sci 63:188-202

Knezevic SZ, Evans SP, Van Acker RC, Lindquist JL (2002) Critical period for weed control: the concept and data analysis. Weed Sci 50:773-786
Knezevic SZ, Streibig JC, Ritz C (2007) Utilizing R software package for dose-response studies: the concept and data analysis. Weed Technol 21:840-848

Kumar V, Jha P (2015) Influence of glyphosate timing on Kochia scoparia demographics in glyphosate-resistant sugar beet. Crop Prot 76:39-45

Kumar V, Jha P, Giacomini D, Westra E, Westra P (2015) Molecular basis of evolved resistance to glyphosate and acetolactate synthase-inhibitor herbicides in kochia (Kochia scoparia) accessions from Montana. Weed Sci 63:758-763

Kumar V, Jha P, Reichard N (2014) Occurrence and characterization of kochia (Kochia scoparia) accessions with resistance to glyphosate in Montana. Weed Technol 28: $122-130$

McKenzie RH, Middleton AB, Bremer E (2005) Fertilization, seeding date, and seeding rate for malting barley yield and quality in southern Alberta. Can J Plant Sci 85: 603-614

McVay K, Burrow M, Jones C, Wanner K, Menalled F (2009) Montana barley production guide. Montana State University Extension Service Publication EB 0186. 2 p

Mithila J, Swanton CJ, Blackshaw RE, Cathcart RJ, Hall JC (2008) Physiological basis for reduced glyphosate efficacy on weeds grown under low soil nitrogen. Weed Sci 56:12-17

Mohler CL (2001) Enhancing the competitive ability of crops. Pages 269-322 in Liebman M, Mohler CL, Staver CP, eds. Ecological Management of Agricultural Weeds. Cambridge, UK: Cambridge University Press

Norsworthy JK, Oliveira MJ (2004) Comparison of the critical period for weed control in wide- and narrow-row corn. Weed Sci 52:802-804

O'Donovan JT, Harker KN, Blackshaw RE, Stougaard RN (2003) Effects of variable tralkoxydim rates on wild oat (Avena fatua) seed production, wheat (Triticum aestivum) yield, and economic return. Weed Technol 17:149-156

O'Donovan JT, Harker KN, Clayton GW, Hall LM (2000) Wild Oat (Avena fatua) interference in barley (Hordeum vulgare) is influenced by barley variety and seeding rate. Weed Technol 14:624-629

O'Donovan JT, Turkington TK, Edney MJ, Juskiw PE, McKenzie RH, Harker KN, Clayton GW, Lafond GP, Grant CA, Brandt S, Johnson EN, May WE, Smith E (2012) Effect of seeding date and seeding rate on malting barley production in Canada. Can J Plant Sci 92:321-330

Peterson DE, Nalewaja JD (1992) Green foxtail (Setaria viridis) competition with spring wheat (Triticum aestivum). Weed Technol 6:291-296

Saxton AM (1998) A macro for converting mean separation output to letter groupings in proc mixed. Pages 1243-1246 in Proceedings of the 23rd SAS Users Group International Conference. Cary, NC: SAS Institute

Scursoni JA, Benech Arnold R (2002) Effect of nitrogen fertilization timing on the demographic processes of wild oat (Avena fatua) in barley (Hordeum vulgare). Weed Sci 50:616-621

Scursoni JA, Satorre EH (2005) Barley (Hordeum vulgare) and wild oat (Avena fatua) competition is affected by crop and weed density. Weed Technol 19:790-795

Sønderskov M, Swanton CJ, Kudsk P (2012) Influence of nitrogen rate on the efficacy of herbicides with different modes of action. Weed Res 52:169-177 
Swanton CJ, Nkoa R, Blackshaw RE (2015) Experimental methods for crop-weed competition studies. Weed Sci 63(Supp. 1): 2-11

[USDA] U.S. Department of Agriculture (2015) Montana Agricultural Facts 2014. Helena, MT: USDA, National Agricultural Statistics Service, Montana Field Office. https://www.nass.usda.gov/ Statistics_by_State/Montana/Publications/Special_Interest_ Reports/agfacts.pdf. Accessed: October 12, 2016

Vencill WK, ed. (2002). Herbicide Handbook. 8th edn. Lawrence, KS: Weed Science Society of America
Yenish JP, Young FL (2004) Winter wheat competition against jointed goatgrass (Aegilops cylindrica) as influenced by wheat plant height, seeding rate, and seed size. Weed Sci 52:996-1001

Received March 21, 2016, and approved August 1, 2016.

Associate Editor for this paper: John Lindquist, University of Nebraska, Lincoln 